\title{
KEMAMPUAN MENYELESAIKAN SOAL CERITA MATEMATIKA
}

\author{
Astra Puspita Kaprinaputri \\ e-mail: astrapk@ymail.com \\ PG PAUD FIP Universitas Negeri Jakarta
}

\begin{abstract}
Abstrak: Penelitian ini bertujuan untuk mendeskripsikan tentang kemampuan menyelesaikan soal cerita matematika siswa Kumon usia 7-8 tahun di bimbingan belajar Kumon, Jakarta Utara yang dilaksanakan pada bulan Desember 2012. Penelitian ini menggunakan pendekatan kuantitatif dengan menggunakan metode survei dan dilaksanakan pada anak yang mengikuti bimbingan belajar Kumon. Prosedur pengumpulan data dilakukan dengan menyebar soal kepada siswa Kumon sebagai respondennya. Analisis data dengan menggunakan tehnik prosentase. Temuan hasil penelitian menunjukkan bahwa kemampuan menyelesaikan soal cerita matematika siswa Kumon usia 7-8 tahun di bimbingan belajar Kumon sebanyak $86 \%$ berada pada kategori tinggi dan $14 \%$ berada pada kategori sedang. Tidak ditemukan siswa Kumon yang berada pada ketgori rendah. Implikasi dari hasil penelitian ini adalah agar siswa Kumon memiliki kemampuan menyelesaikan soal cerita matematika perlu adanya latihan dalam menjabarkan proses penyelesaian soal cerita matematika yang bersifat kontinu. Selain itu, akan lebih baik apabila pihak bimbingan belajar Kumon menggunakan media dalam pengajaran soal cerita matematika.
\end{abstract}

Kata Kunci: kemampuan menyelesaikan soal, soal cerita matematika, media

\section{ABILITY TO SOLVE MATHEMATICS WORD PROBLEMS}

\begin{abstract}
This study aims to describe the ability of Kumon's students, 7-8 years old, in solving mathematics word problems. This study done in December 2012 used cumulative approach with survey method. The respondents were the students of Kuman Course in North Jakarta. The data collected by distributing the questions to the respondents were analyzed applying simple statistic technique. Findings show that $86 \%$ of the respondents belong to high category while $14 \%$ belong to medium category. and no students belongs to low category. The implication of this study is Kumon students have the ability to solve mathematics word problem, but they still have to do more exercises in solving mathematics word problems continually. Besides, the Kumon Course should use media in the teaching of mathematics word problems.
\end{abstract}

Key words: ability to solve problems, mathematics word problem, media.

\section{PENDAHULUAN}

\section{Latar Belakang}

Matematika merupakan salah satu mata pelajaran utama di sekolah. Hal ini disebabkan karena dalam kehidupan sehari-hari manusia membutuhkan kemampuan berhitung. Kemampuan berhitung didapatkan dari hasil pembelajaran matematika. Namun kemampuan berhitung yang biasa digunakan untuk kehidupan sehari-hari tidak serumit pembelajaran matematika di sekolah yang membutuhkan rumus-rumus.

Pembelajaran matematika sangatlah dibutuhkan oleh anak sebagai bekal hidupnya. Namun saat ini matematika dianggap sebagai pelajaran yang sulit dikarenakan harus menggunakan banyak rumus dan banyak juga guru yang masih menggunakan metode pengajaran konvensional, seperti didaktik (didactic teaching) sehingga anak kurang paham atas apa yang diajarkan. Disini guru mengajar dengan memberitahu kepada siswa secara langsung apa materinya dan konsep yang harus dikuasai. Tugas siswa hanyalah menerima, mengingat, dan menghafal.

Hal tersebut diatas tidak dapat diterapkan dalam pengajaran tentang soal cerita karena pada soal cerita anak dituntut untuk bisa menganalisis soal cerita tersebut sampai akhirnya menemukan cara atau operasi yang tepat untuk mengerjakannya. Seperti yang dijelaskan oleh Depatemen Pendidikan Nasional (2009:111) Untuk melatih agar para siswa dapat menyelesaikan soal cerita dengan benar, maka perlu diperhatikan tahapan-tahapan sebagai berikut: (1) mendata hal-hal yang diketahui berdasarkan keteran- 
gan yang termuat dalam soal, (2) mencermati apa yang ditanyakan termasuk satuan-satuan yang ditanyakan, dan (3) menyelesaikan permasalahan berdasarkan apa yang diketahui dan apa yang ditanyakan. Dalam hal ini, soal cerita menggali kemampuan anak dalam mengidentifikasi bagian yang diketahui dari soal cerita matematika, bagian yang ditanyakan oleh soal cerita matematika, dan kemampuan menjawab soal cerita matematika menggunakan operasi yg tepat.

Untuk membantu anak memahami tahapantahapan tersebut, dewasa ini banyak sekali lembagalembaga penunjang yang menyediakan pembelajaran tambahan. Hal ini sering dijadikan sebagai peluang bisnis. Saat ini telah menjamur berbagai lembagalembaga penunjang pendidikan seperti kursus dan les. Salah satu tempat les yang menjadi fenomena tidak hanya di Indonesia tetapi juga di dunia adalah bimbingan belajar Kumon. Bimbingan belajar Kumon ada di 46 negara dan region, walaupun terdapat perbedaan dalam gaya hidup, sistem pendidikan dan kebudayaan. Saat ini bimbingan belajar Kumon memiliki program penunjang pembelajaran matematika dan bahasa Inggris. Namun pembelajaran matematika yang diajarkan oleh bimbingan belajar Kumon telah terlebih dahulu mendunia dan sebagian besar telah terbukti keberhasilannya.

Kemampuan menyelesaikan soal cerita merupakan salah satu kemampuan yang dikembangkan oleh bimbingan belajar Kumon, di sini siswa bimbingan belajar Kumon telah terbiasa mengerjakan soal dengan cara memikirkan penyelesaian soal dan langsung merumuskan jawaban pada lembar kerja yang disediakan, sedangkan disekolah guru meminta anak untuk menuliskan penjabaran penyelesaian soal tersebut pada lembar kerja, karena dalam mengerjakan soal cerita dibutuhkan kemampuan dasar analisis anak agar sesuai dengan tahapan dalam menyelesaikan soal cerita. Oleh karena itu, peneliti ingin melihat sejauh mana kemampuan siswa kelas 2 sekolah dasar dalam menyelesaikan soal cerita matematika, khususnya siswa yang mengikuti bimbingan belajar Kumon.

\section{Kajian Teori}

a. Kemampuan Menyelesaikan Soal Cerita Matematika

Kemampuan menyelesaikan soal cerita sangat dibutuhkan anak dalam pembelajaran matematika disekolah karena hal ini penting untuk dikuaisai oleh anak. Penyelesaian masalah mewakilkan bagian yang sangat penting dari matematika dalam pemecahan masalah ini sering menggunakan kata atau soal cerita yang harus diselesaikan oleh murid (Heddens \& Speer, 2001:40) . Dari pernyataan tersebut dapat dideskripsi- kan bahwa pemecahan masalah sering terdapat pada soal yang menggunakan kata ataupun soal cerita.

Dalam penyelesaian soal cerita terdapat tahapan-tahapan yang harus dilakukan untuk mencapai jawaban yang diinginkan. Terdapat beberapa tahapan dalam penyelesaian soal cerita, yaitu: (1) understand the problem, (2) devise a plan, (3) carry out the plan, dan (4) look back (Polya, 2008:1.12). Anak diminta untuk terlebih dahulu mengerti apa yang dimaksud oleh soal. Seperti apa yang diketahui? Apa saja datanya? dan lain sebagainya. Lalu anak merencanakan pengerjaan soal, misalnya dengan mencari rumus atau operasi yang tepat untuk mengerjakan soal tersebut. Berikutnya anak menjalankan rencana yang telah iya buat dan mengerjakan dengan seksama. Terakhir, anak diminta untuk melihat kembali hasil pekerjaannya, apakah sudah sesuai dengan apa yang diharapkan. Hal ini juga dapat membantu anak apa bila ada proses yang kurang tepat, sehingga anak mempunyai waktu untuk memperbaikinya.

Penyelesaian soal cerita juga menggukan bahasa yang dikenal dalam dunia matematika. Untuk menyelesaikan soal cerita diperlukan kemampuan sebagai berikut: (a) menentukan hal yang diketahui dalam soal, (b) menentukan hal yang ditanyakan dalam soal, (c) membuat model matematika (kalimat matematika), serta (d) melakukan komputasi (perhitungan, dan mengintepretasi jawaban model ke permasalahan soal semula) (Sukarno (2001:5). Dalam menyelesaikan soal cerita sangat diperlukan kemampuan-kemampuan dalam menentukan hal yang diketahui, ditanyakan, membuat model matematika, dan melakukan perhitungan.

Berdasarkan definisi-definisi di atas dapat dideskripsikan bahwa kemampuan menyelesaikan soal cerita sangatlah penting untuk dikuasai oleh anak. Terutama dalam menentukan apa yang diketahui dari soal, apa yang ditanyakan oleh soal, memilih operasi yang tepat, dan menjawabnya dengan jawaban yang tepat.

b. Karakteristik Perkembangan Kognitif Siswa Kelas 2 SD

Di Indonesia siswa kelas 2 sekolah dasar termasuk kedalam periode kelas awal dengan rentang usia 6-8 tahun (Sujiono,2005). Anak yang duduk dibangku kelas 2 sekolah dasar berada pada rentang usia 7-8 tahun. Anak pada usia ini adalah anak yang berada pada periode perkembangan akhir masa kanak-kanak. Pada usia ini anak dikatakan berada pada masa peralihan dari masa kanak-kanak ke masa kanak-kanak akhir yaitu pada usia 8 tahun ke atas.

Ada beberapa kemampuan kognitif anak usia 
6-8 yang bisa dijabarkan. Kemampuan perseptual kognitif anak usia 6-8 tahun meliputi: (1) mampu membedakan kata yang hampir sama; (2) mengenal angka 1 sampai 500; (3) mengenal nilai tempat; (4) mampu memahami konsep penjumlahan dan pengurangan, perkalian dan pembagian, bangun ruang, luas dan waktu; (5) bermain teka-teki atau membuat kata, menyebut huruf atau bunyi awal kata (Sujiono, 2009:162) Kemampuan ini menunjukkan bahwa anak sudah bisa berpikir konkrit dan logis.

Tahapan operasional konkrit merupakan tahapan yang akan anak miliki setelah tahapan preoperasional. Saat anak memasuki tahapan operasional konkrit, mereka lebih mengerti tentang masalah-masalah yang dulu tidak bisa mereka pecahkan pada tahap pra-operasional (Piaget, 2008:286).

Berdasrkan karakteristik aspek perkembangan kognitif, pemikiran anak usia sekolah dasar kelas awal disebut pemikiran operasional konkret (concrete operational thought) (Piaget, 2005:16). Operasi konkret adalah aktivitas mental yang difokuskan pada objekobjek dan peristiwa-peristiwa nyata atau konkret dapat diukur. Pada tahap ini anak-anak dapat berpikir logis dari pada sebelumnya, karena pada tahap ini anak dapat mengambil aspek yang banyak dari situasi yang anak alami, sehingga anak dapat memanipulasi apa yang anak dapat dan memperoleh pengetahuan melalui berbagai percobaan. Berdasarkan pernyataan tersebut, dapat dikatakan bahwa pada tahap ini anak dapat memecahkan masalah dengan bantuan bendabenda konkret.

Sekitar usia 7 tahun anak-anak sudah dapat menggunakan berbagai operasi mental, seperti penalaran, dan memecahkan masalah-masalah konkret (nyata) (Piaget dan Feldman, 2005:16). Selain itu, anak-anak pada usia ini dapat berpikir dengan logis karena anak-anak pada usia ini tidak terlalu egosentris dari sebelumnya dan dapat mempertimbangkan banyak aspek dari situasi. Dengan kata lain, anakanak pada tahap operasional konkret sudah memiliki pemahaman yang lebih baik dari pada anak-anak praoperasional mengenai konsep penalaran dan konsep sebab-akibat memiliki kemampuan untuk memahami konsep-konsep dalam berhitung misalnya konsep penjumlahan dan pengurangan.

Berdasarkan definisi diatas dapat dideskripsikan bahwa anak usia 7-8 tahun berada pada tahap operasional konkret. Operasi konkret adalah aktivitas mental yang difokuskan pada objek-objek dan peristiwa nyata dapat diukur, karena anak sudah bisa berpikir lebih logis debandingkan pada tahap praopersional.

\section{METODE PENELITIAN}

Berdasarkan tujuannya untuk menggambarkan keadaan apa adanya tentang kemampuan menyelesaikan soal cerita matematika siswa Kumon usia 7-8 tahun, penelitian ini menggunakan metode deskriptif dengan pendekatan survey. Penelitian ini tidak diarahkan untuk menguji hipotesis, tetapi diarahkan untuk menggambarkan variable atau kondisi apa adanya dalam suatu situasi. Penelitian deskriptif adalah penelitian yang dimaksudkan untuk mengumpulkan informasi mengenai status suatu gejala yang ada, yaitu keadaan gejala menurut apa adanya pada saat penelitian dilakukan (Arikunto, 2006:309).

Ciri penelitian metode deskriptif, yaitu penelitian berhubungan dengan keadaan yang sedang terjadi, peneliti menguraikan satu per satu variabel, variabel yang diteliti tidak diberikan perlakuan (Kountur, 2007:108). Pendapat tersebut menyatakan bahwa penelitian dengan metode deskriptif bertujuan untuk menggambarkan atau mendeskripsikan mengenai informasi yang sesuai dengan variabel yang diteliti.

Penelitian ini menggunakan pendekatan survey. Survei mendeskripsikan keadaan sesungguhnya yang terjadi pada saat tertentu (Cohen dan Nomion dalam Sukardi, 2011:193). Hal ini berarti bahwa pendekatan 12 Jurnal IImiah VISI P2TK PAUD NI - Vol. 8, No.1, Juni 2013 survey dilakukan dalam penelitian dengan metode deskriptif. Melalui pendekatan ini, peneliti dapat menginformasikan dengan melihat keadaan sesungguhnya yang terjadi dilapangan.

Penelitian ini dilaksanakan di bimbingan belajar Kumon, Jakarta Utara dalam November 2012. Tempat ini dipilih karena daerahnya mudah dijangkau dan memiliki kurang lebih 28 cabang bimbingan belajar Kumon. Selain itu dilokasi tersebut terdapat anak usia 7-8 tahun yang mengikuti bimbingan belajar Kumon.

Populasi pada penelitian ini adalah anak usia 7-8 tahun yang mengikuti bimbingan belajar Kumon di Jakarta Utara dengan jumlah 28 lembaga. Teknik yang digunakan dalam menentukan sempel adalah cluster random sampling. Cluster merupakan kelompokkelompok yang bukan merupakan kelas atau strata (Arikunto, 2006:141). Menurut Margono, cara yang digunakan dalam random sampling adalah: (1) cara undian, (2) cara ordinal, (3) randomisasi dari table bilangan random.

Dalam penelitian ini digunakan cara undian, yaitu sampel diambil dari populasi yang terdiri dari 28 bimbingan belajar Kumon di 10 kecamatan di Jakarta Utara. Setelah dilakukan cluster sampel random, di- 
dapatkan yaitu bimbingan belajar Kumon di wilayah Koja dan Kelapa Gading. Hal ini dapat diartikan bahwa sampel dalam penelitian ini adalah anak usia 7-8 tahun yang mengikuti bimbingan belajar Kumon di wilayah Koja dan Kelapa Gading. Anak usia 7-8 tahun yang dibutuhkan sebagai sampel pada bimbingan belajar Kumon diwilayah Koja sebanyak 18 anak dan diwilayah Kelapa Gading sebanyak 32 anak, sehingga didapatkan sampel dengan jumlah 50 anak usia 7-8 tahun.

Teknik pengumpulan data menggunakan tes untuk mendapatkan informasi tentang kemampuan menyelesaikan soal cerita siswa Kumon usia 7-8 ta- hun, untuk mengukur ada atau tidaknya serta besarnya kemampuan objek yang diteliti, digunakan tes. Adapun kisi-kisi instrumen kemampuan menyelesaikan soal cerita siswa kelas 2 SD di bimbingan belajar Kumon sebagai berikut: (1) melakukan penjumlahan bilangan 2 angka, (2) melakukan pengurangan bilangan 2 angka, (3) melakukan penjumlahan bilangan 3 angka, dan (4) melakukan pengurangan bilangan 3 angka. Sedangkan teknik analsiis data menggunakan uji validitas dari instrumen, dengan rumus product moment untuk mendapatkan hasil yang valid.

\section{HASIL DAN PEMBAHASAN}

\section{Hasil Penelitian}

Berdasarkan hasil survei kemampuan menyelesaikan soal cerita matematika siswa Kumon usia 7-8 tahun di bimbingan belajar Kumon, Jakarta Utara diperoleh skor tertinggi 16, skor terendah 10, dan skor rata-rata 14. Nilai median 14 dan nilai modus 16 . Nilai varians 35.81 serta standar deviasi 1.9. berikut ini data tersebut dideskripsikan melalui table 1.

Tabel 1. Deskripsi Hasil

\begin{tabular}{|c|c|}
\hline Deskripsi Data & Data \\
\hline$\Sigma$ Responden & 50 \\
\hline Mean & 14 \\
\hline Median & 14 \\
\hline Modus & 16 \\
\hline varians & 35,81 \\
\hline Standar Deviasi & 1.9 \\
\hline Skor Maksimum & 16 \\
\hline Skor Minimum & 10 \\
\hline
\end{tabular}

Dengan data tersebut diatas dapat dibuat tabel distribusi frekuensi kemampuan menyelesaikan soal cerita matematika siswa Kumon usia 7-8 tahun di bimbingan belajar Kumon, Jakarta Utara, yang digambarkan dalam tabel 2.

Tabel 2. Kemampuan Menyelesaikan Soal Cerita Matematika Siswa Kumon Usia 7-8 Tahun

\begin{tabular}{|c|c|c|}
\hline Kelas interval & Frekuensi & Frekuensi relatif \\
\hline $10-11$ & 7 & $14 \%$ \\
\hline $12-13$ & 11 & $22 \%$ \\
\hline $14-15$ & 13 & $26 \%$ \\
\hline $16-17$ & 19 & $38 \%$ \\
\hline Total & 50 & $100 \%$ \\
\hline
\end{tabular}

Berdasarkan tabel distribusi frekuensi pada tabel 1, didapatkan kategori untuk responden. Jumlah responden yang berada pada kategori "tinggi" sebanyak 43 responden atau $86 \%$, responden yang berada pada kategori "sedang" sebanyak 7 responden atau $14 \%$, dan tidak ditemukan siswa Kumon usia 7-8 tahun yang berada pada kategori "rendah". Dengan demikian dapat dikatakan bahwa kemampuan menye-lesaikan soal cerita matematika siswa Kumon usia 7-8 tahun berada pada kategori tinggi. Data tersebut dideskripsikan dalam tabel 3.

Tabel 3. Kategori Kelas Interval

\begin{tabular}{|c|c|c|c|}
\hline Kelas interval & Frekuensi & $\begin{array}{c}\text { Frekuensi } \\
\text { relatif }\end{array}$ & Kategori \\
\hline $0-5$ & 0 & $0 \%$ & Rendah \\
\hline $6-11$ & 7 & $14 \%$ & Sedang \\
\hline $12-16$ & 43 & $86 \%$ & tinggi \\
\hline Total & 50 & $100 \%$ & - \\
\hline
\end{tabular}

Hasil penelitian menunjukkan bahwa siswa yang mendapatkan nilai sempurna pada soal cerita penjumlahan 2 bilangan sebanyak $92 \%$ siswa dan pada soal cerita penjumlahan 3 bilangan sebanyak $56 \%$ siswa. Selanjutnya siswa yang mendapatkan nilai sempurna pada soal cerita pengurangan 2 bilangan sebanyak $52 \%$ siswa dan pada soal cerita pengurangan 3 bilangan sebanyak $64 \%$ siswa.

Data tersebut menunjukkan bahwa penjumlahan 2 bilangan merupakan indikator yang paling dikuasai oleh siswa dan indikator yang paling lemah penguasaannya adalah pengurangan 2 bilangan. Siswa dapat menjawab dengan mudah pada soal cerita dengan indikator penjumlahan 2 bilangan karena pada soal tersebut teknik menyimpan yang digunakan tidak banyak dan mempermudah pengerjaan soal. Hal ini dijelaskan dalam pedoman pembelajaran matematika di sekolah dasar, penjumlahan tanpa teknik me- 
nyimpan harus mendahului pengajaran penjumlahan dengan teknik menyimpan. Hal tersebut mendeskripsikan bahwa siswa harus menguasai penjumlahan tanpa teknik menyimpan terlebih dahulu sebelum penjumlahan dengan teknik menyimpan. Oleh sebab itu, siswa lebih mudah mengerjakan soal yang teknik menyimpannya tidak banyak.

Lain halnya dengan soal penjumlahan 3 bilangan, teknik menyimpan yang digunakan lebih banyak. Oleh karena itu, nilai yg diperoleh oleh siswa juga tidak sebaik pada soal penjumlahan 2 bilangan. Namun, siswa menyatakan bahwa pengerjaan soal penjumlaan lebih mudah dibandingkan pengerjaan soal pengurangan. Hal ini sesuai dengan pernyataan dari Ardle, most children find addition an easier process than substraction. Kebanyakan anak menemukan bahwa proses penjumlahan lebih mudah dibandingkan pengurangan. Oleh sebab itu, pada soal cerita dengan indikator pengurangan 2 bilangan, siswa merasa sedikit kesulitan dalam penyelesaiannya. Hal ini disebabkan oleh adanya teknik meminjam dalam penyelesaian soal tersebut.

Sama seperti pada soal penjumlahan, siswa harus menguasai pengurangan tanpa teknik meminjam terlebih dahulu sebelum pengurangan dengan teknik meminjam. Seperti yang telah dinyatakan dalam pedoman pembelajaran matematika di sekolah dasar, pengurangan dengan teknik meminjam dikenalkan setelah pengurangan tanpa teknik meminjam dikuasai anak. Oleh sebab itu, siswa lebih mudah mengerjakan soal tanpa teknik meminjam, seperti soal cerita dengan indikator pengurangan 3 bilangan. Bilangan-bilangan pada soal pengurangan ini dapat dihitung tanpa menggunakan teknik meminjam. Oleh sebab itu, banyak siswa yang memperoleh nilai sempurna dibandingkan pada soal pengurangan 2 bilangan.

Berdasarkan sistematika jawaban, dapat dideskripsikan secara keseluruhan bahwa hampir seluruh siswa Kumon memiliki kemampuan yang baik dalam menyelesaikan soal cerita matematika. Hal ini dikarenakan nilai yang ada termasuk dalam kategori "tinggi". Sebanyak 84\%-100\% siswa mampu menentukan hal yang diketahui dari soal, $80 \%-98 \%$ siswa mampu menentukan hal yang diketahui dari soal, 80\%-98\% siswa mampu membuat kalimat matematika dari soal, dan sebanyak $70 \%-96 \%$ siswa mampu menentukan jawaban dengan tepat. Masih terdapat beberapa kesalahan dalam pengerjaan soal ataupun pengosongan jawaban pada beberapa siswa. Hal ini dikarenakan siswa tidak terbiasa dalam mengerjakan soal cerita dengan menggunakan tahapan penyelesaian. Oleh sebab itu, siswa sering lupa atau melewatkan beberapa bagian yang seharusnya dikerjakan pada soal cerita yang diberikan.

Siswa Kumon mengetahui kemampuan yang dibutuhkan dalam pengerjaan soal cerita yang terdiri dari kemampuan menentukan apa yang diketahui dari soal, kemampuan menentukan apa yang ditanyakan oleh soal, kemampuan membuat kalimat matematika, dan kemampuan menjawab soal dengan tepat. Untuk menyelesaikan soal cerita, diperlukan kemampuan: (1) menentukan hal yang diketahui dalam soal, (2) menentukan hal yang ditanyakan dalam soal, (3) membuat model matematika (kalimat matematika), dan (4) melakukan komputasi (perhitungan, dan mengintepretasi jawaban model ke permasalahan soal semula) (Sukarno, 2001). Hal ini menunjukkan bahwa siswa sebenarnya memiliki kemampuan menyelesaian soal cerita matematika Kemampuan tersebut membuat siswa dapat menyebutkan dan menjelaskan secara individu bagaimana penyelesaian soal cerita matematika saat ditanya. Pengetahuan tentang kemampuankemampuan tersebut didapatkan oleh siswa justru dari sekolah masing-masing. Pihak kumon tidak mengajarkan secara detail tentang bagaimana pengerjaan soal cerita yang sesungguhnya. Namun, dapat dikatakan bahwa siswa kelas 2 SD memiliki kemampuan yang baik dalam menyelesaikan soal cerita matematika, walaupun kemampuan ini tidak didapatkan hanya dari bimbingan belajar Kumon namun juga dari sekolah siswa siswi itu sendiri.

\section{PENUTUP}

\section{Kesimpulan}

Penelitian ini mengkaji kemampuan menyelesaikan soal cerita matematika siswa Kumon usia 7-8 tahun. Penelitian ini dilakukan pada siswa Kumon usia 7-8 tahun dengan menjabarkan kemampuan menyelesaikan soal cerita matematika yang terdiri dari kemampuan menentukan apa yang diketahui dari soal, kemampuan menentukan apa yang ditanyakan oleh soal, kemampuan menyelesaikan soal dengan membuat kalimat matematika, dan kemampuan menjawab soal dengan tepat. Dari hasil keseluruhan data yang didapat dari responden didapatkan nilai rata-rata 14 dengan estimasi parameter rata-rata populasi 13,46 $\leq \mu \leq 14,53$. Berdasarkan sebaran proporsi ditemukan sebanyak 43 responden atau $86 \%$ berada pada kategori "tinggi" dan 7 responden atau $14 \%$ berada 
pada kategori "sedang". Tidak ditemukan responden yang berada pada kategori "rendah". Hal ini dapat diestimasi proporsi populasinya dengan hasil 0,77 $\leq \mathrm{P}$ $\leq 0.95$ untuk kategori tinggi dan $0,05 \leq \mathrm{P} \leq 0,23$ untuk kategori sedang.

Hal ini menunjukkan bahwa sebagian besar atau lebih dari $50 \%$ responden berada pada kategori "tinggi". Namun terdapat beberapa responden yang berada pada kategori "sedang", hal ini dikarenakan terdapat beberapa kesalahan dalam pengerjaan soal ataupun pengosongan jawaban. Beberapa responden mengetahui kemampuan yang dibutuhkan dalam pengerjaan soal cerita yang terdiri dari kemampuan menentukan apa yang diketahui dari soal, kemampuan menentukan apa yang ditanyakan oleh soal, kemampuan membuat model atau kalimat matematika, dan kemampuan menjawab soal dengan tepat, Namun karena tidak terbiasa responden sering lupa atau melewatkan beberapa bagian yang seharusnya dikerjakan pada soal cerita yang diberikan.

Maka dapat ditarik kesimpulan bahwa kemampuan menyelesaikan soal cerita matematika siswa kumon usia 7-8 tahun di bimbingan belajar Kumon, Jakarta Utara sudah baik, dilihat dari hasil tes yang menunjukkan bahwa responden dengan kategori "tinggi" lebih banyak dibandingkan dengan responden yang berada pada kategori "sedang". Namun perlu adanya latihan agar anak dapat mengembangkan kemampuan menyelesaikan soal cerita matematika lebih baik lagi.

\section{Saran}

Berdasrkan keseimpulan di atas, maka saran dalam penelitian ini di antaranya: Pertama, bagi guru sebaikanya guru membantu dan melatih siswa secara kontinu dalam mengembangkan kemampuan menyekesaikan soal cerita matematika yang terdiri dari kemampuan menentukan apa yang diketahui dari soal, kemampuan menentukan apa yang ditanyakan oleh soal, kemampuan membuat model atau kalmat matematika, dan kemampun menjawab soal dengan tepat. Kedua, bagi lembaga bimbingan belajar Kumon hendaknya memperhatikan kemampuan para siswa dengan membuat soal yang dpat membantu anak dalam mengasah kemampuannya dalam menyelesaikan soal cerita matematika. Ketiga, bagi orang tua hendaknya meluangkan waktu untuk siswa dirumah dalam memabantu mengasah kemampuannya menyelesaikan soal cerita matematika, terutama dalam menganalisis soal-soal cerita tersebut. Keempat, bagi peneliti selanjutnya, yaitu dapat menjadi acuan dalam penelitian lain yang berhubungan dengan metode Kumon dan mengupas secara mendalam melalui metode kuantitatif.

\section{DAFTAR PUSTAKA}

Arikunto, S. (2006). Prosedur penelitian: Suatu pendekatan praktek. Jakarta: PT Rineka Cipta.

Depdiknas. (2009). Pedoman Pembelajaran Matematika di Sekolah Dasar. Jakarta: Departemen Pendidikan Nasional.

Desmita. (2005). Psikologi perkembangan. Bandung: PT. Remaja Rosdakarya.

Hidden., \& Speer. (2001). Today is mathematics. New York: Macmillan Publishing.

Kountur, R. (2007). Metode penelitian untuk penulisan skripsi dan tesis. Jakarta: Penerbit PPM.

Muhsetyo, G., dkk. (2008). Pembelajaran matematika
SD. Jakarta: Universitas Terbuka.

Patterson, C. (2008). Child development. Boston: Mcgraw Hill Higher Education.

Sujiono, Y.N. (2005). Menu pembelajaran anak usia dini. Jakarta: Citra Pendidikan.

Sujiono, Y.N. (2009). Konsep dasar pendidikan anak usia dini. Jakarta: Indeks.

Sukardi. (2011). Metodologi penelitian pendidikan kompetensi dan praktiknya. Jakarta: PT Bumi Aksara.

Sukarno. (2001). Pelajaran matematika III. Jakarta: Pandu Karya. 